\title{
Peningkatan Pemahaman Tentang Lembaga Lembaga Negara Pada Mata Pelajaran Pkn Melalui Metode Diskusi Kelompok Siswa Kelas Iv Sd Negeri 15 Raja Ampat Kabupaten Raja Ampat Tahun Pelajaran 2015/2016
}

\author{
Mohamad Tamin, S.Pd. \\ SD Negeri 15 Raja Ampat, Fafanlap Distrik Misool Selatan
}

\begin{abstract}
Based on the evaluation of students' learning result on the material of state institutions of Civic Subject, it could be identified that IV grade students of SD Negeri 15 Raja Ampat Regency have difficulty in understanding state institutions of govermental structures. Therefore, researcher tried to improve students' understanding on the material of state institutions of Civic Subject using group discussion. This research is a classroom action research which involved two cycles. Every cycles consisted of four steps, those were planning, action, observation and reflection. The subject of this research was IV grade students of SD Negeri 15 Raja Ampat Regency which consisted of 28 students. The data collection techniques used were interview, observation, documentation and test. The data was analyzed qualitatively and quatitatively. Based on the result, the average score of cycle I was 62,5 or 46,42\% and the average score on the cycle II was 90 or 85,71\%. Based on that score, it could be concluded that there was improvement on students' learning result on every cycle. Thus, the use of group discussion on the material of state institutions of Civic Subject for IV grade students at SD Negeri 15 Raja Ampat have improved.

Keywords: state institutions, Civic Subject, learning result, group discussion, SD Negeri 15 Raja Ampat
\end{abstract}

\begin{abstract}
Abstrak: Berdasarkan data hasil evaluasi belajar siswa tentang lembaga-lembaga Negara dapat diidentifikasi bahwa siswa Kelas IV Sekolah Dasar Negeri 15 Raja Ampat mengalami kesulitan memahami lembaga-lembaga negara dalam susunan pemerintahan tingkat pusat dengan benar. Oleh karena itu, peneliti berusaha meningkatkan pemahaman siswa kelas IV pada mata pelajaran PKn materi lembaga-lembaga Negara dengan menggunakan metode diskusi kelompok. Penelitian ini merupakan penelitian tindakan kelas yang dilaksanakan dalam dua siklus. Masing-masing siklus terdiri dari empat tahap, yaitu perencanaan, tindakan, pengamatan dan refleksi. Subjek pada penelitian ini adalah siswa kela IV SD Negeri 15 Raja Ampat yang berjumlah 28 siswa. Teknik pengumpulan data yang digunakan dalam penelitian ini adalah wawancara, observasi, dokumentasi dan tes. Data dalam penelitian ini dianalisis secara kualitatif dan kuantitatif. Berdasarkan hasil penelitian, diperoleh rata-rata pada siklus I sebesar 62,5 atau $46,42 \%$ dan nilai rata-rata pada siklus II adalah 90 atau $85,71 \%$. Berdasarkan nilai tersebut dapat disimpulkan bahwa telah terjadi peningkatan hasil belajar pada setiap siklus. Dengan demikian, penggunaan metode diskusi kelompok dalam pembelajaran tentang lembaga-lembaga Negara mata pelajaran PKn pada siswa kelas IV SD Negeri 15 Kabupaten Raja Ampat meningkat.
\end{abstract}

Kata kunci: lembaga Negara, PKn, hasil belajar, diskusi kelompok, SD Negeri 15 Kabupaten Raja Ampat 


\section{Pendahuluan}

Pendidikan Kewarganegaraan kemudian disingkat PKn merupakan usaha untuk membekali siswa dengan pengetahuan dan kemampuan dasar berkenaan dengan hubungan antara warga negara dengan negara serta pendidikan pendahuluan bela negara. Mata pelajaran Pendidikan Kewarganegaraan disusun secara sistematis, komprehensif, dan terpadu dalam proses pembelajaran menuju kedewasaan dan keberhasilan dalam kehidupan di masyarakat. Adapun fungsi mata pelajaran pendidikan Kewarganegaraan di SD adalah membentuk warga negara yang cerdas, terampil, dan berkarakter, serta setia kepada bangsa dan negaraIndonesia yang berdasarkan Pancasila dan Undang - Undang Dasar 1945.

Berdasarkan karakteristiknya, penyampaian materi pelajaran PKn sangat cocok apabila menerapkan metode diskusi. Namun, selama ini sebagian besar guru dalam memberikan pelajaran PKn kepada siswanya dengan cara yang monoton, proses belajar mengajar yang hanya menggunakan metode ceramah menyebabkan materi pelajaran yang diperoleh siswa hanya sebatas wacana saja. Siswa hanya duduk memperhatikan penjelasan guru, tanpa diberi kesempatan untuk bertanya. Jika hal ini menjadi kebiasaan guru sehari-hari di sekolah, maka akan membentuk kebiasaan perilaku yang tidak baik bagi anak, seperti kurang responsif, sulit mengajukan pendapat, dan bersifat pasif terhadap suatu hal. Sering kali terjadi dalam menjelaskan materi pelajaran PKn, guru biasanya hanya menggunakan sebuah buku sumber dan LKS saja. Guru hanya menjelaskan materi pembelajaran apa yang tertulis pada buku sumber dan LKS tersebut. Guru tidak memberi tambahan pengalaman atau pengetahuan lain. Pada saat proses pembelajaran berlangsung, kelas didominasi oleh guru. Siswa hanya berperan sebagai pendengar setia saja. Akibatnya muncul berbagai tingkah laku siswa yang kurang baik diantaranya ada yang mengantuk karena tidak berminat sudah merasa bosan dan capek mendengarkan ceramah guru, ada yang pasif terhadap penjelasan guru. Begitu selesai menjelaskan materi pelajaran, guru langsung memberi tugas kepada siswa untuk menjawab pertanyaan-pertanyaan yang ada pada LKS. Begitu mengerjakan, siswa mengalami kesulitan dalam menjawab pertanyaan karena kurang atau tidak memahami maksud dari pertanyaannya. Perilaku guru yang seperti ini akan membawa dampak yang kurang baik bagi siswa. Terutama bagi siswa yang kemapuannya rendah, mereka akan memilih untuk diam dan akan berbuat yang menyimpang misalnya ramai, bergurau, serta tidak berminat mengikuti pelajaran. Setelah siswa menyelesaikan pekerjaannya, guru mengajak siswa membahas hasil pekerjaan siswa. Setelah dikoreksi ternyata hasil yang 
diperoleh adalah sebagian siswa mendapatkan nilai dibawah SKBM yaitu 70 untuk mata pelajaran PKn di Sekolah Dasar Negeri 15 Raja Ampat.

Oleh sebab itu sebagai upaya meningkatkan hasil belajar siswa, peneliti menerapkan metode diskusi pada mata pelajaran PKn dengan harapan penerapan metode diskusi dapat membuat siswa untuk selalu berpikir kritis dan terarah dalam memecahkan suatu masalah. Baik masalah yang berhubungan dengan pelajaran di sekolah maupun masalah dalam kehidupan sehari-hari sebagai tujuan jangka panjangnya. Sedangkan bagi guru sendiri, penerapan metode diskusi akan memotivasi untuk lebih kreatif dan inovatif dalam menyiapkan diskusi, membimbing diskusi, dan menyimpulkan hasil diskusi. Sehingga ketika pembelajaran berakhir, siswa benar-benar memperoleh hasil belajar yang bermakna.

\section{Metode Penelitian}

\subsection{Desain Penelitian}

Penelitian ini merupakan penelitian tindakan kelas. Penelitian tindakan kelas ini bertujuan untuk Meningkatkan pemahaman siswa tentang lembaga-lembaga Negara pada mata pelajaran PKn melalui metode diskusi kelompok pada siswa kelas IV. Penelitian tindakan kelas ini dilakukan dalam dua siklus dimana masing-masing siklus terdiri dari 4 tahapan, yaitu: perencanaan, tindakan, observasi dan refleksi.

\subsection{Subjek Penelitian}

Subjek dalam penelitian tindakan kelas ini adalah siswa kelas IV SD Negeri 15 Kabupaten Raja Ampat yang berjumlah 28 siswa. Siswa kelas IV terdiri dari 17 siswa laki-laki dan 11 siswa perempuan. Mata pelajaran yang menjadi objek penelitian adalah mata pelajaran PKn, dengan materi pokokmengenal lembaga -lembaga negara dalam susunan pemerintahan tingkat pusat.

\subsection{Lokasi dan Waktu Penelitian}

PTK ini dilaksanakan di Sekolah Dasar Negeri 15 Raja Ampat Kabupaten Raja Ampat. PTK ini terdiri dari beberapa siklus.

\subsection{Prosedur Penelitian}

Penelitian tindakan kelas terdiri atas beberapa rangkaian, yaitu: empat kegiatan yang dilakukan dalam siklus berulang. Empat kegiatan utama menurut Arikunto (2008: 74) yang ada pada setiap siklus, yaitu : (a) perencanaan, (b) tindakan, (c) pengamatan, dan (d) refleksi. 
Penelitian tindakan kelas ini terdiri dari siklus-siklus dengan pemberian tes awal atau tes sebelum siklus. Tiap siklus dilaksanakan sesuai dengan perubahan yang dicapai seperti yang telah didesain dalam faktor yang diselidiki. Apabila sudah diketahui letak keberhasilan dan hambatan dari tindakan yang dilaksankaan pada siklus pertama, maka peneliti menentukan rancangan untuk siklus-siklus berikutnya.

Tahapan penelitian tindakan kelas meliputi :

1) Perencanaan Tindakan

Sebelum pelaksanaan tindakan pada setiap siklus, dibuat perencanaan tindakan. Sedangkan perencanaan tindakan sebelum melaksanakan siklus berikutnya berupa revisi perencanaan tindakan berdasarkan hasil observasi, skor tes hasil belajar siswa dan hasil refleksi yang diperoleh.

2) Pelaksanaan Tindakan

Tindakan yang diberikan pada subjek penelitian adalah melakukan pembelajaran tentang lembaga-lembaga Negara pada mata pelajaran PKn melalui metode diskusi kelompok pada siswa kelas IV.

3) Observasi

Observasi yang dilakukan adalah mengamati proses pembelajaran berlangsung dan mencatat hal-hal yang diperlukan.

4) Refleksi

Refleksi dilakukan baik di setiap akhir pertemuan pada setiap siklus dan setelah pemberian tes hasil belajar pada setiap siklus. Refleksi di setiap akhir siklus dilaksanakan berdasarkan hasil belajar dan observasi. Analisis hasil observasi dan hasil belajar juga dilaksanakan dalam tahap ini. Dari hasil yang diperoleh dilakukan refleksi diri atas kekurangan-kekurangan yang terjadi pada setiap pertemuan.

\subsection{Teknik Pengumpulan data}

Teknik pengumpulan data yang digunakan dalam penelitian ini adalah dokumentasi, wawancara, observasi dan tes.

\subsection{Teknik Analisis Data}

Hasil dari pengumpulan data akan dianalisis dan dikelompokkan berdasarkan jenis data yaitu data kuantitatif dan data kualitatif. Data kuantitatif adalah data yang berupa angka atau numerik. Dalam hal ini yang termasuk data kuantitatif adalah data yang berisi tentang penugasan dan hasil tes yang dianalisis dengan menggunakan statistik deskriptif yaitu dengan menghitung rata-rata (mean), rentang, dan nilai maksimum dan minimum yang diperoleh siswa pada setiap bahasan. Sedangkan data kualitatif adalah data yang 
berbentuk kata-kata. Dalam hal ini yang termasuk data kualitatif adalah hasil observasi aktivitas siswa pada setiap siklus.

\section{Hasil Penelitian dan Pembahasan}

\subsection{Hasil Penelitian}

Berdasarkan hasil pengamatan dan analisis hasil belajar siswa pada siklus I, serta hasil diskusi peneliti dengan teman sejawat, diputuskan bahwa perlu dilaksanakan perbaikan pembelajaran siklus yang kedua. Menurut catatan teman sejawat masih ada beberapa kelemahan atau kekurangan-kekurangan di dalam pelaksanaan perbaikan siklus yang pertama. Hasil evaluasi belajar siswa menunjukkan bahwa rata-rata keberhasilan belajar siswa 62,5 atau sebesar $46,42 \%$.

Selanjutnya, pada siklus II, berdasarkan analisis lembar pengamatan diskusi dapat disimpulkan bahwa prestasi siswa dalam kegiatan diskusi menunjukkan peningkatan yang cukup baik. Penggunaan alat peraga sudah cukup mendukung belajar siswa, diskusi pun dapat berjalan dengan baik. Ditinjau dari hasil evaluasi belajar siswa menunjukkan bahwa siswa yang mendapat nilai 70 keatas sebanyak 28 Anak. Nilai rata-rata kelas mencapai 90 atau $85,71 \%$. Nilai evaluasi yang telah dicapai oleh siswa jika dihubungkan dengan Standar Ketuntasan Belajar Minimal yang telah ditetapkan di Sekolah, maka hasil belajar siswa pada perbaikan pembelajaran siklus II telah diatas standar ketuntasan minimal, yaitu 70 untuk mata pelajaran PKn.

\subsection{Pembahasan}

\section{Siklus I}

Pada pelaksanaan perbaikan pembelajaran siklus I ini, dapat dikatakan berhasil dan juga belum berhasil. Mengapa demikian, jika ditinjau dari analisis hasil evaluasi belajar siswa, nilai rata-rata masih dibawah SKBM Sekolah Dasar Negeri 15 Raja Ampat. Kegagalan ini berhubungan dengan apa yang disampaikan oleh teman sejawat pada komentarnya, yaitu :

1) Apersepsi yang disampaikan oleh guru, kurang maksimal. Upaya guru untuk meningkatkan motivasi siswa kurang, hal ini terlihat masih ada beberapa siswa yang terlihat pasif di dalam pembelajaran. Hal ini sangat berpengaruh terhadap gairah belajar siswa. Jika gairah belajar siswa rendah akibatnya hasil belajar siswa juga akan rendah.

2) Pengelolaan kelas masih kurang. Pada waktu diskusi kelompok masih ada siswa yang mengganggu temannya sehingga membuat kelas menjadi gaduh. 
3) Diskusi kelompok didominasi oleh siswa- siswa yang pandai saja, sedangkan yang lain masih terlihat pasif. Hal ini dapat mengakibatkan siswa yang pasif akan tertinggal oleh siswa-siswa yang mendominasi diskusi di dalam kelompoknya.

\section{Siklus II}

Pelaksanaan perbaikan pembelajaran siklus II ini dapat dikategorikan berhasil menurut SKBM Sekolah Dasar Negeri 1 AsemrudungKeberhasilan ini dapat tercapai karena peneliti berusaha memenuhi kelemahan-kelemahan pada pelaksanaan pembalajaran siklus I sebagaimana komentar teman sejawat. Peneliti berpedoman bahwa dengan menggunakan metode pembelajaran bervariasi yang disertai alat peraga, dapat mengefektifkan pembelajaran. Pembelajaran siklus II, peneliti memfokuskan pada pemecahan masalah dalam memahami lembaga-lembaga negara di tingkat pusat. Peneliti menerapkan motede diskusi, karena berdasarkan karakteristiknya metode diskusi adalah salah satu metode yang digunakan untuk menyampaikan materi pelajaran kepada peserta didik yang bersifat problematis.

\section{Kesimpulan Dan Saran}

\subsection{Kesimpulan}

Berdasarkan data-data yang dihimpun oleh peneliti dari pelaksanaan pembelajaran siklus I dan siklus II, peneliti menarik beberapa kesimpulan yaitu:

1. Peningkatan hasil belajar peserta didik kelas IV Sekolah Dasar Negeri 15 Raja Ampat mata pelajaran PKn dalam memahami lembaga-lembaga negara di tingkat pusat telah tercapai;

2. Penerapan metode pembelajaran diskusi kelompok sangat efektif bagi tercapainya tujuan pembelajaran yang akan dicapai.

\subsection{Saran}

Berdasarkan kesimpulan di atas peneliti dapat memberikan saran, bahwa untuk menyampaikan materi pembelajaran PKn khususnya dalam materi mengenal lembagalembaga negara, hendaknya disertai alat peraga yang berupa bagan, dalam hal ini berupa bagan lembaga negara. Penggunaan alat peraga dapat:

1) memberikan kemudahan kepada peserta didik untuk lebih memahami konsep, sikap dan keterampilan tertentu;

2) memberikan pengalaman belajar yang berbeda dan bervariasi sehingga lebih merangsang minat peserta didik untuk belajar; 
3) menumbuhkan sikap dan keterampilan tertentu dalam tehnologi karena peserta didik tertarik untuk menggunakan atau mengoperasikan media tertentu;

4) menciptakan situasi belajar yang tidak dapat dilupakan peserta didik.

Selain penggunaan alat peraga guru hendaknya menerapkan metode yang bervariasi. Dengan penggunaan metode pembelajaran yang bervariasi dapat menciptakan kegairahan belajar siswa, karena siswa tidak merasa jenuh. Jika guru menerapkan satu jenis metode pembelajaran saja dalam menyampaikan materi, dapat menyebabkan siswa cepat bosan yang dapat mengakibatkan semangat belajar siswa akan menurun.

Begitu pula tentang pengelolaan waktu. Guru harus pandai-pandai dalam mengelola waktu dengan sebaik-baiknya. Terutama jika guru menerapkan metode pembelajaran diskusi. Biasanya metode diskusi banyak menyita waktu. Jika guru tidak pandai-pandai mengelola waktu, materi belum selesai waktunya sudah habis, sehingga menyita waktu mata pelajaran yang lain.

\section{Daftar Pustaka}

Andayani, dkk. 2008. Pemantapan Kemampuan Profesional. Jakarta: Universitas Terbuka Hernawan, Asep H, dkk. 2006. Pengembangan Kurikulum dan Pembelajaran. Jakarta: Universitas Terbuka

Mikarsa, Hera Lestari, dkk. 2007. Pendidikan Anak di SD. Jakarta: Universitas Terbuka Sumantri, Mulyani. 1999. Strategi Belajar Mengajar. Jakarta: Depdibud Dirjen Dikti Proyek PGSD

Wardani, I.G.A.K, Wiharditka dan nasoetion, N. 2007. Penelitian Tindakan Kelas. Jakarta: Universitas Terbuka

Wahyudin, H. Dinn, dkk. 2004. Pengantar Pendidikan. Jakarta: Universitas Terbuka

Winataputra, Udin. S. 2006. Materi dan Pembelajaran PKn SD. Jakarta: Universitas Terbuka

Zainul, Asmawi, dan Maulana, Agus . 2005. Tes dan Assessment di SD. Jakarta: Universitas Terbuka. 